\title{
Effect Of Marketing Mix, Service Quality, And University Image On Student Loyalty
}

\author{
Radiman $^{1}$, Sri Fitri Wahyuni ${ }^{2}$, Jufrizen ${ }^{3}$, Muslih $^{4}$, Dedek Kurniawan Gultom ${ }^{5}$ and Salman Farisi ${ }^{6}$ \\ \{radiman@umsu.ac.id ${ }^{1}$ \} \\ 1,2,3,4,5,6 Faculty of Economics and Business, University of Muhammadiyah Sumatera Utara, Jalan Kapten \\ Muchtar Basri No. 3 Medan, Indonesia
}

\begin{abstract}
This research aims to investigate the impact of the marketing mix, service quality, and university image on student's loyalty. The main purpose of the study is divided into three sub-goal of investigating the effect of the marketing mix on student's loyalty, investigates the effect of service quality on student's loyalty and investigates the influence of university image on student loyalty. Questionnaires were distributed to the students as much as 200 questionnaires using Likert scale, yet only 167 questionnaires are returned. To process the data is used SPSS version 21. The results showedmarketing mix variable, service quality, and university image and a significant positive effect on student loyalty.
\end{abstract}

Keywords: Marketing mix, service quality, university image, loyalty, student

\section{Introduction}

Education is an important factor for the progress of the Indonesian people. Educational development is a top priority in the national development agenda in achieving progress in the social, economic, political and cultural fields. The government seeks to prioritize development in the field of education, especially the quality of education so that it can produce quality and superior human resources (HR). Educational institutions are places for the establishment of quality human resources so that they can be prepared for future development. The education sector experiences intense competition in fighting over the "market" to attract prospective students. Competition occurs among State Universities and Private Universities. High competition demands a good marketing strategy from all universities to attract prospective students from various high schools in Indonesia. Prestigious competition is not only in favorite State Universities but also in favorite Private Universities. Prospective students have the freedom to choose the name of a college because they choose a college that is able to fulfill or satisfy their expectations. Satisfied students are loyal to the college concerned, then the student will recommend to prospective students a certain university name if the facilities offered by the higher education institution are compared to the names of other universities.

Interest of prospective students to choose college greatly are influenced by their perception of the higher education. Students choose the university that they already know and have a good image. A person's attitude and actions of an object is determined by their belief in the image of the object (Kotler \& Keller, 2012) The image is the set of beliefs, ideas and influence that a person of an object (Kusdiyanto, 2008).

Image as a set of beliefs, ideas, and influences a person gets from an object. A person's attitude and actions towards objects are largely due to the image of the object (Kotler \& Keller, 2012). The success of universities in forming images is influenced by several factors, such as the completeness of facilities and infrastructure, the history of the university, and the success in providing services to students. Higher Education will highlight the advantages it 
has so that the community has its own assessment of the image of the college. (Kotler \& Keller, 2012) revealed that each producer tries to design meaningful differences to differentiate their products from the products offered by their competitors, so that each product has its own characteristics that differentiate it from its competitors' products.

Customer satisfaction is the customer's response to a mismatch between the level of prior importance and actual performance that is felt after usage (Rangkuti, 2002). The principle is that there are 3 keys to providing customer satisfaction (Tjiptono, 2008), namely the ability to understand customer needs and desires including understanding customer types, developing an accurate database of customers including the needs and desires of each customer segment, utilizing information obtained from market research within the strategic marketing framework.

Loyalty is the result of a combination or multidimensional relationships of various interests, attitudes, achievement of sales and customer behavior (Palmatier, Dant, Grewal, \& Evans, 2006). A student who is loyal to the college should not only take advantage of the institution, but it must have feelings and cognitions a positive attitude to the institution as a basic motivation to behave (Hennig-Thurau, Langer, \& Hansen, 2001). In other words, loyalty, students should not only benefit or advantage to the college at the time of active college students on campus; but of course a greater advantage is that after graduating college students. To achieve such loyalty (Gilmore, 2008) suggested that the college match the program to students who experience obstacles in their education or professional business. (Gilmore, 2008) also states that the college needs to cut ties and problems that hinder the successful graduation of students and to appoint staff who can help social work and extracurricular activities.

Furthermore, develop student understanding that loyalty is determined based on the quality of relationships, both when students are still actively attend college or after graduation (Hennig-Thurau et al., 2001). Loyalty active college student during the student can be integrated into the system at a university, the quality of teaching, the emotional commitment to the institution and external commitments. The quality of teaching can be positively enhanced by the active participation of students in the process of service delivery. This can be done, for example by allowing the lecturers involved in the discussions and jointly develop classroom atmosphere to stimulate teaching, encouraging students to participate in research activities to actively assist in designing and collecting research data.Therefore, the ultimate goal of this research is to investigate the impact of themarketing mix, service quality, and university image of the student's behavior. The main purpose of the study is divided into three sub-goals:

1. To investigate the effect of the marketing mix on student's loyalty.

2. To investigate the effect of service quality on student's loyalty.

3. To investigate the effect of university image on student's loyalty.

\section{Literature Review}

\subsection{Loyalty}

Loyalty is defined as a deep commitment to repurchase or repeat the pattern of preference for a product or service in the future, which causes repeated purchases of the same brand or a set of brands, even though there are involvement of situational factors and marketing efforts that have the potential to cause shifting behavior brand (Engel, 1990). That loyalty is a value obtained from a long-term relationship because a person feels gain many benefits from the relationship (Egan, 2007). While (Griffin, 2002) expressed his opinion on consumer loyalty is the concept of loyalty is more directed to the behavior compared with an 
attitude and a loyal customer will demonstrate behavior of purchase is defined as a buyer who organized and displayed all the time by some units of the decision-making. Loyalty is something that causes consumers can choose a brand, services, stores, products and specific activities. More loyalty to a feature that is owned by the consumer, and not just to something related to a brand (Hammond, Uncles, \& Dowling, 2003). Loyalty is one of the ways consumers to express their satisfaction will be the performance of the products or services they receive (Bloemer and Kasper, in (Ballester \& Aleman, 2001) Sizes for customer loyalty varies, one of which is through the four components, namely consumers' willingness to buy / reuse of products or services that are the same in the future, the willingness of consumers to recommend products or services that they use to others, tolerance prices applied to products or services and the willingness to adopt a cross which is to buy / use other products from the same brand or company with the products they have used (Gronholdt, Martensen, \& Kristensen, 2000).

\subsection{Marketing Mix}

Marketing mix is the set of marketing tools used marketing to achieve marketing objectives in the target market (Kotler \& Keller, 2012). In service companies the application of marketing mix variables needs to be added from the marketing mix concept is the process of people, and physical evidence. Being there are seven marketing mixes for services that are products, prices, places, promotions, processes, people and physical evidence (Zeithaml, Bitner, \& Gremler, 2009). Marketing mix is defined as an element of organizational control that can be used to meet or to communicate with consumers (Zeithaml et al., 2009). Booms and Bitner According in (Kotler \& Keller, 2012), that for marketing services, variable marketing mix 4P's coupled with 3P's to become 7P's (Oliver, 1980). Likewise (Goncalves, 1998); (Kotler \& Fox, 2005), that the marketing strategy on education in the world, the ideal is the marketing strategy known 7P's: program, price, place, promotion, processes, physical evidence, and people.

\subsection{Service Quality}

Lewis and Booms (Lewis \& Booms, 1983) service quality is a measure of how well the level of service provided is able to meet customer expectations. Whereas according to (Zeithaml et al., 2009) Quality of service is the expected level of excellence and control of the level of excellence to meet customer desires. Service quality is centered on efforts to fulfill consumer needs and desires as well as the accuracy of delivery for offset consumer expectations, namely the existence of a match between expectations and management perceptions, there is compatibility between perceptions of consumer expectations with employee work standards, there is a match between employee work standards with services provided with the promised service and presence conformity between services received and those expected with consumer (Sunyoto, 2012). (Tjiptono \& Chandra, 2011) that service or service component play a strategic role in every business. Purchase an item oftencoupled with service / service elements. Vice versa, a service is often expanded by entering or adding physical products to the offer the service. Generally services are more intangibles, cannot be seen and touched so that the user can only be felt through direct experience. But service includes things that are tangibles, which can be seen and touched, in the form of the physical dimension of the service itself. 


\subsection{University Image}

The image as a set of beliefs, ideas, and influence that a person from an object. Attitudes and actions are toward the object in large part because of the image of the object (Kotler \& Keller, 2012). The image is the set of beliefs, ideas and influence that a person of an object (Kusdiyanto, 2008). (Abd-El-Salam, Shawky, \& El-Nahas, 2013) namely the general impression left in mind consumers as a result of a collection of feelings, ideas, attitudes and experiences with companies that are stored in memory. The impression is then transformed into a positive or negative image according to feeling and consumer experience with the company. Both positive and negative images then it will be recalled when the company name is heard or carried into consumer memory. (Andreassen, 1994) revealed that corporate image is positively correlated with customer loyalty. Customer loyalty higher as a result of good corporate image implies a higher market share and ability to demand prices that are relatively higher than competitors ((Herington, Johnson, \& Scott, 2006) and (Fortunato, 2000). Besides that, image effective and good companies are also considered as determinants in customer satisfaction. The conceptual framework of this study, as shown below:

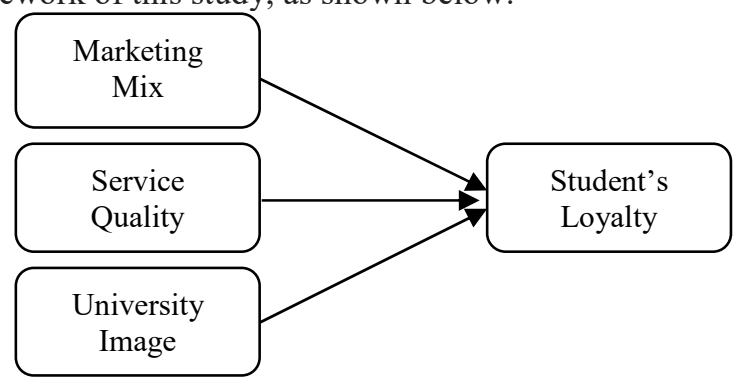

Fig.1. Conceptual Framework.

\section{Research Methods}

The sample size can be calculated from the amount of indicator multiplied by 5 to 10 . Because this study uses four variables construct overall number of indicators by 40 , so that the required sample in this study a minimum of $5 \times 40=200$. The location of this study is conducted a few College of Islamic Religion of Private in Medan as University of Muhammadiyah Sumatra Utara, University of Islamic Sumatra Utara, University of Muslim Nusantara and University of Alwasliyah. Data is collected by interviews and questionnaires. The data analysis technique used is descriptive and multiple regression.

\section{Result And Discussion}

\subsection{Normality Test}

Normality test is among the significant statistical analysis is primary research and the test which applies on the data to check either it is normally distributed or not (Waluyo, 2018). Data normality was examined by considering Skewness and kurtosis roomates follow the concept of (Meyers, Gamst, \& Guarino, 2006). Based on the data is said to be normally distributed if the range of Skewness as well as kurtosis lies between \pm 1.0 and \pm 3.00 respectively. In the current study, it is found that all the values exist between \pm 1.0 and $\pm 3: 00$. Hence, the data was normal and proceeded for further analysis.

\subsection{Correlation Analysis}


Correlation analysis is used to measure the linear association between the two variables. The correlation value of 1 indicates that the variables are perfectly positively correlated whereas the value of -1 indicates that the variables are perfectly negatively correlated and the correlation value of 0 indicates that there is no correlation between the variables (Waluyo, 2018). Examining the correlation value, it is found that all the variables have strong correlation. Marketing mix, service quality, and university image have a weak correlation value image 0.318 , and 0.406 and 0.386 respectively. Additionally, it is found that the correlation is significant and positive.

\subsection{Hypothesis}

Regression analysis was used to test the hypothesis. For this purpose, the p-value and $\beta$ value was considered. For a significant $\mathrm{p}$-value relationship should be less than 0:05 ( $\mathrm{p} \leq$ 0,05 ). Table 2 showsthat the results of regression analysis. Table 2 shows that the marketing mix has a significant relationship with student loyalty having p-value of 0.000 . Beta value 0104 shows a positive relationship. Hence, H1 is accepted. Similarly, the relationship of service quality and university image on student loyalty is also significant with p-value of 0.000 and 0:00, a beta value of 0.220 and 0.134 , respectively. Hence, $\mathrm{H} 2$ and $\mathrm{H} 3$ are also accepted. It indicates that the marketing mix enhances the image quality and the university student loyalty.

Table 1. Regression Results.

\begin{tabular}{ccccc}
\hline Hypothesis & $\begin{array}{c}\text { Variable } \\
\text { Model }\end{array}$ & SE & P & Results \\
\hline $\mathrm{H} 1$ & $\mathrm{MM} \rightarrow$ SL & 0,019 & 0,000 & Supported \\
\hline $\mathrm{H} 2$ & $\mathrm{SQ} \rightarrow \mathrm{SL}$ & 0,041 & 0,000 & Supported \\
\hline $\mathrm{H} 3$ & $\mathrm{UI} \rightarrow \mathrm{SL}$ & 0,024 & 0,000 & Supported \\
\hline
\end{tabular}

Note:

$\mathrm{MM}=$ Marketing Mix, SQ = Service Quality, UI = University Image, SL = Student Loyalty

\subsection{Effect of Marketing Mix on Student Loyalty}

Based on hypothesis testing, it is known that the marketing mix positive and significant impact on student loyalty. This means, if it is better the marketing mix is applied, then increasing the loyalty of these students. Empirically, this experiment research findings support the results of the research are conducted by (Becket \& Brookes, 2008), (Ogunnaike et.al, 2014), and (Thalib, 2015) which showed that there is an influence on marketing mix of student loyalty.

\subsection{Effect of Service Quality on Student Loyalty}

Based on hypothesis testing, it is known that the service quality positive and significant impact on student loyalty. This means, if it is more and better service quality, and then increase the loyalty of these students. The results are consistent with the results of research that has been done (Fares, Achour, \& Kachkar, 2013), (Usman \& Mochtar, 2016) and (Ganić, Babić-Hodović, \& Arslanagić-Kalajdžić, 2018) which showed that service quality significantly influence student loyalty. Likewise, a study isconducted by (Noviasari, et.al, 2015) which showed that service quality significantly influence student loyalty.

\subsection{Effect of University Image On Student Loyalty}


Based on hypothesis testing, it is known that the university image positive and significant impact on student loyalty. This means, if it is better the university image in the eyes of the students, then increase the loyalty of these students. The results are consistent with the results of research that has been done (Alves \& Raposo, 2010), (Jiewanto, Laurens, \& Nelloh, 2012), (Fares et al., 2013), (Barusman, 2014), (Noviasari et al., 2015) and (Usman \& Mochtar, 2016), that showed that the university image significantly influence student loyalty.

\section{Conclusion}

This study concludes that the marketing mix has effect on student loyalty. Thus, the higher perceived marketing mix; the loyalty of the students will be higher as well. Service quality effect on student loyalty. Thus, the higher perceived service quality; the loyalty of the students will be higher. University image has effect on student loyalty. Thus, the higher perceived university image, the loyalty of the students will be higher as well. There are some suggestions can be given, namely, the university needs to consider the factors that shape the loyalty of students, such as students have a high loyalty to the university, loyal students to the course chosen, and loyal students to the subjects that followed. Due to gain reputation, students should feel satisfaction first. To achieve the loyalty of students, the University needs to improve the marketing mix, service quality, and university image.

\section{References}

[1] Abd-El-Salam, E. M., Shawky, A. Y., \& El-Nahas, T. (2013). The impact of corporate image and reputation on service quality, customer satisfaction and customer loyalty: testing the mediating role. Case analysis in an international service company. The Business \& Management Review, 3(2).

[2] Alves, H., \& Raposo, M. (2010). The influence of university image on students' behavior. International Journal of Educational Management, 24(1), 73-85. https://doi.org/10.1108/09513541011013060

[3] Andreassen, T. W. (1994). Satisfaction, Loyalty and Reputation as Indicators of Customer Orientation in the Public Sector. Journal of Public Sector Management, 7(2), 16-34.

[4] Ballester, E. D., \& Aleman, J. L. M. (2001). Brand trust in the context of consumer loyalty. European Journal of Marketing, 35(11/12), 1238-1258. https://doi.org/https://doi.org/10.1108/EUM0000000006475

[5] Barusman, A. R. P. (2014). Student Satisfaction as a Mediating Variable between Reputation, Image and Student Loyalty, 1, 414-436.

[6] Becket, N., \& Brookes, M. (2008). Quality Management Practice in Higher Education - What Quality Are We Actually Enhancing? Journal of Hospitality, Leasure, Sports and Tourism Education, 7(1), 40-54.

[7] Egan, J. (2007). Relationship Marketing: Exploring Relational Strategies in Marketing. Harlow UK: Pearson Education.

[8] Engel, J. (1990). Satisfaction; A Behavioral Perspective On The Consumer. USA: Mc Graw Hill Companies Inc.

[9] Fares, D., Achour, M., \& Kachkar, O. (2013). The Impact of Service Quality, Student Satisfaction, and University Reputation on Student Loyalty: A Case Study of International Students in IIUM, Malaysia. Information Management and Business Review, 5(12), 584-590.

[10] Fortunato, J. A. (2000). Public Relations Strategies for Creating Mass Media Content: 
A Case Study of the National Basketball Association. Public Relations Review, 26(4), 481-497.

[11] Ganić, E., Babić-Hodović, V., \& Arslanagić-Kalajdžić, M. (2018). Effects of Servperf Dimensions on Students' Loyalty -Do You Know what is Behind the Scene. International Journal of Business and Social Science, 9(2).

[12] Gilmore, A. (2008, February). Educating to Ensure Soft Skills. Certification Magazine. Retrieved from http://certmag.com/educating-to-ensure-soft-skills/

[13] Goncalves, K. P. (1998). Service Marketing, A Strategic Approach. New Jersey: Prentice Hall. Inc.

[14] Griffin, J. (2002). Customer Loyalty: How to Earn It, How to Keep It (Revised). New York, United States: John Wiley \& Sons Inc.

[15] Gronholdt, L., Martensen, A., \& Kristensen, K. (2000). The relationship between customer satisfaction and loyalty: Cross-industry differences. Total Quality Management, 11(4-6), 509-514.

[16] Hammond, K., Uncles, M. D., \& Dowling, G. R. (2003). Customer Loyalty and Customer Loyalty Programs. Journal of Consumer Marketing, 20(4), 294-316. https://doi.org/10.1108/07363760310483676

[17] Hennig-Thurau, T., Langer, M. F., \& Hansen, U. (2001). Modeling and Managing Student Loyalty: An Approach Based on the Concept of Relationship Quality. Journal of Service Research, 3(4), 331-345.

[18] Herington, C. ., Johnson, L., \& Scott, D. (2006). Internal Relationships Linking Practitioner Literature and Relationship Marketing Theory. European Business Review, 18(5), 364-381.

[19] Jiewanto, A., Laurens, C., \& Nelloh, L. (2012). Influence of Service Quality, University Image, and Student Satisfaction toward WOM Intention: A Case Study on Universitas Pelita Harapan Surabaya. Procedia - Social and Behavioral Sciences, 400((2012)), 16-23.

[20] Kotler, P., \& Fox, K. F. (2005). Strategic Marketing fo Educational Institutions (2nd ed.). New Jersey: Prentice Hall. Inc.

[21] Kotler, P., \& Keller, K. L. (2012). Marketing Management (13th ed.). New Jersey: Person Preantice Hall. Inc.

[22] Kusdiyanto. (2008). Citra perguruan tinggi swasta di kopertis wilayah vi jawa tengah. BENEFIT Jurnal Manajemen Dan Bisnis, 12(2), 150-160.

[23] Lewis, R. ., \& Booms, B. (1983). The marketing aspects of service quality. In $A M A$ Proceeding (pp. 99-104). American Marketing Association Chicago.

[24] Meyers, L. S., Gamst, G., \& Guarino, A. J. (2006). Applied Multivariate Research Design and Interpretation. Thousand Oaks, London, New Delhi: Sage Publications.

[25] Noviasari, R. A., Wulandari, D., \& Suryaningsih, I. B. (2015). Pengaruh Citra Institusi Dan Kualitas Layanan Terhadap Kepuasan Dan Loyalitas Mahasiswa Universitas Moch. Sroedji Jember. Jurnal Bisnis Dan Manajemen, 9(2), 190-201.

[26] Ogunnaike, O. O., Borishade, T. T., Adeniyi, S., \& Omolade, O. O. (2014). Empirical Analysis of Marketing Mix Strategy and Student Loyalty in Education Marketing. Mediterranean Journal of Social Sciences, 5(23), 616-625.

[27] Oliver, R. L. (1980). A Cognitive Model of the Antecedents and Consequences of Satisfaction Decisions. Journal of Marketing Research, 17(4), 460. https://doi.org/10.2307/3150499

[28] Palmatier, R. W., Dant, R. P., Grewal, D., \& Evans, K. R. (2006). Factors Influencing the Effectiveness of Relationship Marketing: A Meta-Analysis. Ssrn, 70(October), 
136-153. https://doi.org/10.2139/ssrn.904647

[29] Rangkuti, F. (2002). Measuring Customer Satisfaction. Jakarta: PT. Gramedia Pustaka Utama.

[30] Sunyoto, D. (2012). Dasar-dasar manajemen pemasaran. Yogyakarta: CAPS.

[31] Thalib, S. (2015). The Effect of Services Marketing Mix and Customer Value on Satisfaction, Trust, and LoyaltyNo Title. International Journal of Advanced Research2, 3(9), 935-949.

[32] Tjiptono, F. (2008). Service Management Mewujudkan Layanan Prima. Bandung: Alfabeta.

[33] Tjiptono, F., \& Chandra, G. (2011). Service, Quality and Satisfaction. Yogyakarta: Andi.

[34] Usman, U., \& Mochtar, S. S. M. (2016). Analysis of Service Quality, Uinversity Image, and Student Satifaction on Student Loyalty in Higher Education in Nigeria. International Business Management, 10(12), 2490-2502.

[35] Waluyo. (2018). The Effect of Tax Service Quality in Promoting Online Tax System in Indonesia. . . Journal of Applied Economic Sciences, XIII(3 (57)), 649-654.

[36] Zeithaml, V. A., Bitner, M. J., \& Gremler, D. D. (2009). Services Marketing Integrating Customer Focus Across The Firm. New York: Mc Graw Hill Companies Inc. 